\title{
Empire and Italian Landscape in Statius: Silvae 4.3 and 4.5
}

\author{
Christopher M. Chinn
}

Joy Connolly, writing about Vergil's Eclogues in 2001, wrote that pastoral characters "walk simultaneously in the bucolic setting of Theocritus and in a 'real' sociopolitical Italy of civil war, land confiscations, and rivalry for patronage, and that the actions taken in one realm appear to reverberate in the other." Connolly continued: "as [Panofsky] saw it, the relation between the referential reality of Roman Italy and the pastoral text is not realism, not symbol, not metaphor, not allegory, but the contiguous and interpenetrating relation of metonymy." ${ }^{1}$ This description of the relationship between literary and actual history may be extended to other genres of Latin literature as well. Horace's Sabine farm is a real place inflected by both Archaic and Hellenistic poetic precedents. ${ }^{2}$ Lucan's world is the site of both civil war and Homeric combat. ${ }^{3}$ Cicero's Roman statesmen sit in the shade of a Platonic tree. ${ }^{4}$ Statius' Silvae also frequently represent an Italian landscape inflected by the literary tradition. Pollius Felix' maritime villa overlooks a Bay of Naples fraught with Vergilian references (Silv. 2.2.72-82). ${ }^{5}$ Statius' stroll through the Saepta (Silv. 4.6.1-4) echoes Horace's stroll through the Forum in the famous

1 J. Connolly, 'Picture Arcadia: The politics of representation in Vergil's Eclogues', Vergilius 47 (2001), 89-116, esp. 94-95. Cf. M. Leigh, 'Vergil's second Eclogue and the class struggle', Classical Philology 111 (2016), 406-433, esp. 408-411. All Latin texts from ост series. All translations from the Loeb Classical Library.

2 D. Spencer, 'Horace's garden thoughts: Rural retreats and the urban imagination', in R. Rosen and I. Sluiter (eds.) City, Countryside, and Spatial Organization of Value in Classical Antiquity (Leiden 2006), 239-274, esp. 244-245.

3 See e.g, M. Lausberg, 'Lucan und Homer', in W. Haase and H. Temporini (eds.), ANRW 2.32.2 (Berlin 1985), 1565-1622, esp. 1576-1577 who argues that Caesar and Pompey are influenced by Achilles and Agamemnon.

4 A.D. Leeman and H. Pinkster (eds.), M. Tullius Cicero, De Oratore Libri III. Band I: Buch 1, 1-165 (Heidelberg 1981), 76-77.

5 See S.E. Hinds, 'Cinna, Statius, and "immanent literary history", in E.A. Schmidt (ed.), L'histoire littéraire immanente dans la poésie latine (Geneva 2001), 221-257, esp. 246-249. 
pest poem (Sat. 1.9). ${ }^{6}$ In all these instances, the troping of the landscape as a metaliterary metaphor poses an epistemological problem for approaching the real historical meaning of the landscape. In terms of the theme of this volume, the impact of Empire on the landscape in literary texts is obscured by these texts' self-referentiality.

As noted, the intertextuality of Statius' landscapes contains elements of pure self-referentiality: Statius' "Bay of Naples" situates the villa description of Silv. 2.2 within literary history, while his "Saepta" indicates the genre of satire with which he is playing in Silv. 4.6. In such instances, how can we uncover the real landscape in the text? One approach, usefully employed by Francesca Martelli, is to reverse the metaliterary tropes. ${ }^{7}$ Scholars have long noticed that Statius borrows the figure, ultimately derived from Callimachus, of muddy and clear-running rivers: nitente cursu / tranquillum mare proximumque possim / puro gurgite provocare Lirim ("I can challenge the smooth sea with my shining course and neighboring Liris with my limpid stream," Silv. 4.3.93-94). ${ }^{8}$ Here the appearance of the river stands in for the style of poetry. We may, however, reverse the direction of figuration so that the metaphor says something about the actual referents of the Statian text. ${ }^{9}$ In this way the content of the intertext becomes a figure for the 'real' landscape (at least as perceived by the poet). So Martelli has perceptively shown that Statius reverses the river-poetry trope to illustrate what a river actually

6 A. Hardie, Statius and the Silvae: Poets, Patrons, and Epideixis in the Graeco-Roman World (Liverpool 1983), 139; K. Coleman, Statius Silvae IV (Oxford 1988), 176; G. Laguna Mariscal, 'Satirical elements in Statius' Silvae: A literary and sociological approach', in R.R. Nauta, H.-J. Van Dam and J.J.L. Smolenaars (eds.), Flavian Poetry (Leiden 2006), 245-255, esp. 248249; R. Nagel, 'Statius' Horatian Lyrics, Silvae 4.5 and 4.7', CW 102 (2009), 155-156; A. Bonadeo, L'Hercules Epitrapezios Novi Vindicis. Introduzione e commento a Stat. silv. 4,6 (Naples 2010), $57-59$.

7 F. Martelli, 'Plumbing Helicon: Poetic property and the material world of Statius' Silvae', $M D$ 62 (2009), 145-177.

8 Cf. C. Newlands, Statius' Silvae and the Poetics of Empire (Cambridge 2002), 306-308; J.J.L. Smolenaars, 'Ideology and poetics along the Via Domitiana: Statius Silvae 4.3', in R. Nauta et al. (eds.), Flavian Poetry (Leiden 2006), 223-244, esp. 231-232; F. Morzadec, 'Stace et la Sibylle: rivalité littéraire autour de la louange de Domitien la Silve IV, 3', in M. Bouquet et al. (eds.), La Sibylle: parole et representation (Rennes 2004), 85-98, esp. 95 argues that Vulturnus is a metaphor for Statius' poem. A. Loio, 'Commemorating events: the victoria Sosibii in Statius, Silvae 4.3', CQ 62 (2012), 281-285 explores in detail the (metaliterary) intertext between our poem and Callimachus' Victoria Sosibii.

9 See D. Goguey, 'Le paysage dans les Silves de Stace: conventions poétiques et observation réaliste', Latomus 41 (1982), 6o2-613 on the mixture of reality and literary-historical tradition in Statius' landscapes. 
looked like after the channelization. ${ }^{10}$ Rather than a 'pure stream' standing in for excellent poetry, the non-silted river can be imagined in terms of the aesthetics of Callimachean verse.

We may take this interpretive strategy a step further. Recall the interpenetration of art and politics in Vergilian pastoral, which we saw could be extended to other genres. If the Statian intertext contains traces of the politics already inscribed in such writers as Vergil and Horace, then it follows that the tropereversal strategy may illustrate how politically and socially situated actors actually viewed such things as the landscape. This approach could go a long way toward addressing the problem of literary landscapes posed by Connolly and could help us understand the impact of Empire on the landscape. I will proceed by showing how Statius reverses tropes found in Vergil (e.g., the imperial politics of Aeneas' visit to the future site of Rome) and Horace (e.g., the politics of patronage of the Sabine Farm). We will see that in these tropes the landscape says something about politics (that is, landscape becomes more or less a metaphor). I will then argue that Statius exploits these inscribed politics to say something about the 'real' landscape. By focusing on political tropes, I hope to illustrate the impact of empire on the landscape in Statius' Silvae. In this paper, I will examine the presentation of the landscape in Silvae 4.3 (on the construction of the Via Domitiana) and in Silv. 4.5 (a lyric ode honoring the north African immigrant Septimius Severus).

Silv. 4.3 celebrates the completion of a new highway along the Campanian coast from Sinuessa to Puteoli. ${ }^{11}$ This long hendecasyllabic poem introduces its subject with a priamel $(1-26)$, then describes the road construction process $(27-66)$. The rest of the poem is largely devoted to two speeches by mythological figures: the River Vulturnus (67-94) and the Cumaean Sibyl

$10 \quad$ Martelli 2009 op. cit. (n. 7), 157-158. Cf. C. Chinn, "The ecological highway: environmental 4.3', in C. Schliephake (ed.), Ecocriticism, Ecology, and the Cultures of Antiquity (Lanham 2017), 113-130, esp. 121-122.

11 On this poem see H. Cancik, Untersuchungen zur lyrischen Kunst des P. Papinius Statius (Hildesheim 1968), 108-115; Coleman 1988, op. cit. (n. 6), 102-135; F. Kleiner, "The trophy on the bridge and the Roman triumph over nature', AC 6o (1991), 182-192; Newlands 2002, op. cit. (n. 8), 284-325; Morzadec 2004 op. cit. (n. 8), 85-98; Smolenaars 2006, op. cit. (n. 8), 223-244; Martelli 2009, op. cit. (n. 7), 156-158; Loio 2012, op. cit. (n. 8); Chinn 2017, op. cit. (n. 10). 
(114-end). Both speakers praise the emperor Domitian as the builder of the road. The new road and improved landscape thus stand in for the excellence of Domitian and become figures of praise. The poem is also replete with allusions to Vergil. This fact adds a metaliterary layer to the panegyrical presentation of the road (i.e., the "road" becomes the course of literary history). The Campanian landscape, therefore, may be understood as representing praise discourse with an appropriately Vergilian pedigree. Nevertheless, the real landscape of coastal Campania lies behind the poem, and indeed the physical features of the landscape seem to have left their mark on the text. ${ }^{12}$ In political terms, Kleiner has shown (via numismatic and epigraphical evidence) that triumphal arches associated with bridges convey a sense of victory over nature (rather than military conquest). ${ }^{13}$ Accordingly, Statius' poem refers to a triumphal arch adjacent to the bridge over the Vulturnus (Silv. 4.3.95-100), while claiming that Domitian is "greater and more powerful than nature" (Silv. 4.3.135) $\cdot{ }^{14}$ Similarly, Smolenaars reports that an inscription from Puteoli suggests that Statius' language borrows from contemporary propaganda about the time-saving aspects of the new road (aestuantes / septem montibus admovere Baias, Silv. 4.3.26 colonia ... Puteolana ... Vrbi ... admota, AE 1973, 137). ${ }^{15}$ In both these instances, political messages have been literally inscribed in the landscape. Statius has thus reproduced a contemporary linkage of landscape and politics. I want to look at this linkage in the two speeches and examine how they exploit the political troping of the landscape already present in Vergil's Aeneid and Eclogues.

12 E.g., Goguey 1982, op. cit. (n. 9), 604 argues that Statius is more realistic about viticulture around Mt Gaurus than, say, Horace.

13 Kleiner 1991, op. cit. (n. 11), 186-192.

14 Kleiner 1991, op. cit. (n. 11), 184-186. Control over rivers may even have been a codified (in the lex de imperio Vespasiani) prerogative of the Flavian emperors (and presumably then a part of their propaganda program): see C. Bruun, 'Cola di Rienzo and the Lost Clause on Changing the Course of Rivers in the Lex de imperio Vespasiani', in F. Nasti and F. Reduzzi (eds.), Per una comune cultura dell'acqua dal Mediterraneo all'America del Nord (Cassino 2012), 109-134.

15 Smolenaars 2006, op. cit. (n. 8), 227; K. Coleman, 'Stones in the forest: epigraphic allusion in the Silvae', in R. Nauta et al. (eds.), The Poetry of Statius (Leiden 2008), 39-40. Cf. J. Blänsdorf, 'Drei römische Dichter über Straßenbau und Reiseverkehr', in J. Blänsdorf (ed.), Vorträge und Aufsätze zur lateinischen Literatur der Antike und des Mittelalters (Frankfurt am Main 2015), 379-38o. 


\title{
$2 \quad$ The River Vulturnus
}

Scholars have long noted that the Vulturnus episode in Silvae 4.3 is modeled on the manifestation of Tiberinus to Aeneas in Aeneid $8 .{ }^{16}$ Vulturnus' appearance and posture generally recall the Vergilian Tiberinus. Compare the following passages:

\author{
At flavum caput umidumque late \\ crinem mollibus impeditus ulvis \\ Vulturnus levat ora maximoque \\ pontis Caesarei reclinus arcu \\ raucis talia faucibus redundant ... \\ Stat. silv. 4.3.67-71
}

But Vulturnus raises his face, his yellow head and mop of watery hair tangled with soft sedge. Leaning against the mighty arch of Caesar's bridge, he pours from his hoarse throat such words as these ...

Huic deus ipse loci fluvio Tiberinus amoeno

populeas inter senior se attollere frondes

visus (eum tenuis glauco velabat amictu

carbasus, et crinis umbrosa tegebat harundo),

tum sic adfari et curas his demere dictis ...

Verg. Aen. 8.31-35

He dreamed that before him the very god of the place, Tiberinus of the pleasant stream, raised his aged head amid the poplar leaves; fine linen draped him in a mantle of grey, and shady reeds crowned his hair. Then thus he spoke to him, and with these words took away his cares ...

Prefatory to delivering a speech to their addressees, both rivers take human form and raise their faces from the water with their hair covered in foliage. ${ }^{17}$ Statius' redundant, moreover, both acts as a playful metaphor of speaking and

16 Morzadec 2004, op. cit. (n. 8), 94-95; Smolenaars 2006, op. cit. (n. 8), 229. See M. Tueller, 'Well-read heroes quoting the Aetia in Aeneid 8', HSPh 100 (2000), 364-371 on the metapoetic and Callimachean aspects of Aeneas' vision of Tiberinus.

17 Additionally, Statius 'corrects' Vergil (whose Tiberinus is clothed in garment described as glaucus) by employing the color word flavus (line 67) which is more typical of descriptions of the Tiber (cf. the first appearance of Tiberinus in the Aeneid, Aen. 7.30-34). See 
as an 'Alexandrian footnote' (through the prefix re-) affirming that we have seen this kind of speaking river before. ${ }^{18}$ In addition, several phrases in the Vulturnus' speech echo the Vergilian Tiburinus:

\author{
recti legibus alvei ligasti! \\ [...] \\ sed grates ago servitusque tanti est, \\ quod sub te duce, te iubente, cessi, \\ quod tu maximus arbiter meaeque \\ victor perpetuus legere ripae. \\ et nunc limite me colis beato
}

Stat. silv. 4.3.75, 79-85

[you] who bound me in the law of a straight channel [...] But I give you thanks and my servitude is worthwhile because I have yielded under your guidance at your command, and because men shall ever read of you as supreme arbiter and conqueror of my bank.

ipse ego te ripis et recto flumine ducam ...

[...]

mihi victor honorem

persolves. ego sum pleno quem flumine cernis

stringentem ripas et pinguia culta secantem, caeruleus Thybris, caelo gratissimus amnis.

Verg. aen. 8.57, 61-64

I myself will guide you along the banks straight up the stream [...] To me you will pay your tribute when victorious. I am he whom you see grazing my banks with full flood and cleaving the rich tilth - the blue Tiber, river best beloved of Heaven.

Here the parallels may be seen in the notions of a straight channel, military victory, and the effect of rivers on cultivated land (on these parallels, see below). Overall, when Vulturnus describes the landscape (including himself

Coleman 1988, op. cit. (n. 6), 120 as well as L. Fratantuono and R. Alden Smith. (eds.), Virgil Aeneid 8. Text, Translation, and Commentary (Leiden 2018), 174.

18 Smolenaars 2006, op. cit. (n. 8), 229 points out that redundat is used by Cicero to describe practitioners of the Asianist style. Cf. Newlands 2002, op. cit. (n. 8), 307. See Loio 2012, op. cit. (n. 8), 281-282 and Chinn 2017, op. cit. (n. 10), 119-120 on speaking rivers. 
qua river), our view is inflected by the Vergilian intertext: the journey down the new road is like Aeneas' journey to Evander's village and to the future site of Rome; hence the road description is like Vergilian poetry.

Moreover, scholars have often noted how Vergil figures pre-Trojan Italy as a kind of mythical Golden Age. ${ }^{19}$ Indeed, not too long after the Tiberinus epiphany, Evander explicitly refers to the Golden Age of Saturn's exile in Italy (aurea ... / saecula, Aen. 8.324-325). Statius acknowledges this connection by having his Vulturnus refer to Domitian in terms that allude to Eclogue 4 and its heralding of a new Golden Age. Vulturnus proclaims Domitian's leadership by echoing Vergil's address to Asinius Pollio (te duce, te iubente, Stat. silv. 4.3.82 $\sim$ te consule ... / [...] / te duce, Verg. ecl. 4.8-10). ${ }^{20}$ Statius understands Eclogue 4 as an imperial narrative, since he has substituted the emperor for the consul Pollio and since he has juxtaposed Eclogue 4 with the journey to the future site of Rome in Aeneid 8. Statius, in other words, tropes the fourth Eclogue, and its ideal pastoral landscape, as signaling the Golden Age of "Arcadia" in the (Arcadian) Evander's realm in the Aeneid. In the intertext, the Vergilian landscape (Tiber, Rome, and the agricultural ease of the Golden Age) infects Statius' presentation of Campania and may be understood as a figure for the peace and prosperity of the imperial regime. As imperial praise, Statius' poem engages in self-referential response to Vergil's imperial discourse.

What does this intertext mean for Statius' presentation of the actual Campanian landscape? Notice, first of all, that the Vergilian Tiberinus promises to convey Aeneas to Evander's dwelling by means of his "straight flow" (recto flumine, Aen. 8.57). The adjective rectus has been used here in a mildly transferred sense since recto flumine plainly means "by rhe fastest route."21 Statius' Vulturnus, on the other hand, praises Domitian for his creation of "straight channel" (recti ... alvei, Silv. 4.3.75) to prevent destructive flooding. Statius has literalized and physicalized the adjective in response to the Vergilian pretext. In other words, the Vergilian intertext, which figures the journey upriver as a synecdoche for the establishment of Rome and empire, may be read as a figure

19 The classic formulation of this idea is in A. Parry, "The two voices of Virgil's "Aeneid", Arion. A Journal of Humanities and the Classics 2 (1963), 66-8o, here 68. Cf. R. Moorton, 'The innocence of Italy in Vergil's Aeneid', AJPh 110 (1989), 105-130 and C. Perkell, 'The Golden Age and its contradictions in the Poetry of Vergil', Vergilius 48 (2002), 3-39 on the ambiguity of Vergil's Golden Age. Cf. A. Zanker, 'Late Horatian lyric and the Virgilian Golden Age', AJPh 131 (2010), 495-516 on Horace's interpretation of Vergil's Golden Age. I cannot find acknowledgment of this intertext anywhere. Strangely, Smolenaars 2006, op. cit. (n. 8), 237 sees an allusion in me duce (131) to te duce in the Fourth Eclogue but not here.

21 Fratantuono and Smith 2018, op. cit. (n. 17), 166. 
for the physical landscape. The "straight path" to Roman politics and power becomes a straightened river channel because of Roman politics and power. In other words, the landscape of the Golden Age became a figure of Augustan politics. Statius, on the other hand, has shown us Domitianic policies inscribed within the literal landscape, and has thus suggested an actualization of the Golden Age.

Second, the Vergilian Tiberinus proclaims his divine status by referring to his ability to irrigate agricultural land (stringentem ripas et pinguia culta secantem, Aen. 8.63). As Fratantuono and Smith point out, this is a proleptic reference to "the rich and abundant agricultural life of the future Rome." ${ }^{22}$ The landscape thus becomes a figure for the Aeneid's teleological narrative of Roman history. The Statian Vulturnus, on the other hand, has been prohibited from literally destroying cultivated land (e.g., rapere terras, 4.3.79) through channelization (limite me colis beato, 4.3.85). ${ }^{23}$ Likewise, Tiberinus asserts that he will receive honor from Aeneas once he has become a victor in the war against the Latins (Aen. 8.61-62). Vulturnus, by contrast, names Domitian as a "victor" over his riverbanks as a way to praise the channelization project. By using victor figuratively, Statius has emphasized the physical landscape that Domitian's project has modified. In Vergil, the physical river and landscape become figures of divine power and imperial history. In Statius, flooding has literally been controlled and farmland preserved on account of the emperor's power. The Golden Age of the Vergilian pretext (where the ease of agriculture is a figure for Augustan prosperity) thus becomes literalized within the agricultural benefits of Domitian's improvements to Vulturnus' river valley. Domitian has physically enacted an agricultural "Golden Age" through the road-building project and, ultimately, the reach of imperial power.

After a brief interlude describing the greatly reduced travel times afforded by the new road (95-113), Statius introduces his second major internal speaker, the Cumaean Sibyl. Scholars have noted that Statius' Sibyl is manifestly a Vergilian character: ${ }^{24}$

\footnotetext{
22

Fratantuono and Smith 2018, op. cit. (n. 17), 173. Tueller 200o, op. cit. (n. 16), 364-366 points out that Tiberinus here quotes Callimachus and his 'aetiological' discourse.

23 Notice how Statius seems to answer Vergil's culta with colis.

24 Smolenaars 2006, op. cit. (n. 8), 236; Morzadec 2004, op. cit. (n. 8), 86-97.
} 
vates sanctior incipit, tacendum est.

en et colla rotat novisque late

bacchatur spatiis viamque replet!

Stat. silv. 4.3.120-122

A holier bard begins, we must be silent. See! She whirls her neck and wanders at large over the new spaces, filling the road.

tuque, o sanctissima vates,

praescia venturi ...

[...]

at Phoebi nondum patiens immanis in antro

bacchaturvates ...

Verg. Aen. $6.65,77-78$

And you, most holy prophetess, who foreknow the future. [...] But the prophetess, not yet brooking the sway of Phoebus, storms wildly in the cavern ...

Here, Statius' Sibyl reenacts her prophetic frenzy from Aeneid 6. Statius' sanctior is an ironic intergeneric footnote, transferring control of the narrative from Statius (the vates-poet of the occasional Silvae) to the Sibyl (the vatesprophetess of epic). ${ }^{25}$ To emphasize this intertext, Statius' Sibyl compares Domitian to Aeneas: ${ }^{26}$

ex quo me duce praescios Averni

Aeneas avide futura quaerens

lucos et penetravit et reliquit

Stat. silv. 4.3.131-133

... since Aeneas with me to guide both entered and left Avernus' prescient grove, eager to learn the future.

This 'plot summary' of Aeneid 6 again emphasizes Statius' self-referentiality by placing the Sibyl literally in the role of poeta doctus and by placing praise of Domitian literally into the epic tradition. Moreover, Françoise Morzadec

25 Morzadec 2004, op. cit. (n. 8), 89 .
$26 \quad$ Morzadec 2004, op. cit. (n. 8), 87 . 
points out that the Sibyl is essentially a feature of the 'Campanian landscape' (i.e., Vergilian literary history), appearing as she does "at the end of the road":27

Sed quam fine viae recentis imo,

qua monstrat veteres Apollo Cumas,

... cerno?

Stat. silv. 4.3.114-116

But who is this that I see at the furthest end of the new road, where Apollo points to ancient Cumae?

Once again, Statius has embedded his Campania within a Vergilian intertext and a Vergilian character within the Campanian landscape. The situation resembles Connolly's formulation of Theocritean characters populating rural Italy in Vergil's Eclogues. And indeed, scholars have noted that the Sibyl's speech appropriates elements of Anchises' speech later in Aeneid 6:28

en hic est deus, hunc iubet beatis

pro se Iuppiter imperare terris

$[\ldots]$

iuravit tibi iam nivalis Arctus,

nunc magnos Oriens dabit triumphos.

ibis qua vagus Hercules et Euhan

ultra sidera flammeumque solem

et Nili caput et nives Atlantis

Stat. silv. 4.3.128-129, 153-157

See! He is a god, him Jupiter commands to rule the happy earth in his stead ... Already the snowy north has sworn you fealty; now the east shall give you great triumphs. You shall go where Hercules and Euhan wandered, beyond stars and flaming sun and Nile's fount and Atlas' snows.

hic vir, hic est, tibi quem promitti saepius audis,

Augustus Caesar, divigenus, aurea condet saecula qui rursus Latio regnata per arva

Saturno quondam, super et Garamantas et Indos

proferet imperium; iacet extra sidera tellus,

27 Morzadec 2004, op. cit. (n. 8), 87.

28 Smolenaars 2006, op. cit. (n. 8), 237-238; Morzadec 2004, op. cit. (n. 8), 88, 91. 
extra anni solisque vias, ubi caelifer Atlas axem umero torquet stellis ardentibus aptum. huius in adventum iam nunc et Caspia regna responsis horrent divum et Maeotia tellus, et septemgemini turbant trepida ostia Nili. nec vero Alcides tantum telluris obivit ...

$[\ldots]$ nec qui pampineis victor inga flectit habenis Liber, agens celso Nysae de vertice tigris. Verg. Aen. 6.791-801, 804-805

And this in truth is he whom you so often hear promised you, Augustus Caesar, son of a god, who will again establish a golden age in Latium amid fields once ruled by Saturn; he will advance his empire beyond the Garamants and Indians to a land which lies beyond our stars, beyond the path of year and sun, where sky-bearing Atlas wheels on is shoulders the blazing star-studded sphere. Against his coming both Caspian realms and the Maeotic land even now shudder at the oracles of their gods, and the mouths of sevenfold Nile quiver in alarm. Not even Hercules traversed so much of earth's extent [...] nor he either, who guides his car with vine-leaf reins, triumphant Bacchus, driving his tigers down from Nysa's lofty peak.

Through the intertext, Statius compares Domitian and Augustus both directly and in terms of the territory over which they rule (via allusive toponyms). Both leaders are depicted, moreover, as having a kind of divine or cosmic power over the universe. Notice that Vergil asserts that Augustus' rule will coincide with a return of the Golden Age (lines 792-793). Statius acknowledges this by having his Sibyl quote Vergil's fourth Eclogue: ${ }^{29}$

magnus te manet ordo saeculorum

Stat. silv. 4.3.147

A great chain of centuries awaits you.

ultima Cumaei venit iam carminis aetas;

magnus ab integro saeclorum nascitur ordo.

Verg. ecl. 4.4-5

29 Smolenaars 2006, op. cit. (n. 8), 240; Morzadec 2004, op. cit. (n. 8), 89. 
Now is come the last age of Cumaean song; the great line of the centuries begins anew.

As noted, the Sibyl's Aeneid references compare Domitian to Augustus, and the 'future' conquests of Augustus to the actual conquests of Domitian. Here, the allusion activates both the pastoral Golden Age of the fourth Eclogue and the rhetoric of the imperial Golden Age presaged in the Aeneid 6 passage (aurea condet / saecula, Aen. 6.792-793). Just like Vergil, Statius transforms the Golden Age into a narrative of imperial history, this time equating imperial conquest with the return of an easy agricultural existence. The landscape and agriculture, in other words, are figures of this imperial narrative.

Nevertheless, there are two key literalizations in the Sibyl episode. The first may be seen in Statius use of the phase magnus ... ordo saeculorum (Silv. 4.3.147). In its own context (i.e., without the Vergilian inflection) these words refer to the (potentially) extraordinary length of Domitian's life: the phrase is glossed two lines earlier by the words "series of ages" (seriem ... aevi, Silv. 4.3.145) and later by the mythological exempla of Nestor, Tithonus, and the Sibyl herself (Silv. 4.3.150-152). Ordo in Statius thus refers to the sequence of years that have been accorded to Domitian by fate. In Vergil, ordo is a metonymy for the Golden Age and is linked, through nascitur, to the birth and growth of the mysterious child two lines later (nascenti puero, Ecl. 4.7). ${ }^{30}$ To emphasize his trope-reversal, Statius links the ordo of Domitian's life to the Vergilian narrator's prayer to live long enough to celebrate the child's accomplishments (manet ordo, 4.3.147 longae maneat pars ultima vitae, Ecl. 4.53). Statius thus literalized, albeit with hyperbole, the phrase ordo saeculorum as a sequence of years. ${ }^{31}$

The second literalization may be seen in the Sibyl's allusions to Aeneid 6, where the Golden Age represents the peace and prosperity resulting from Augustus' military conquest (see above). In Statius' narrative, Domitian's military conquest (again, intertextually linked to Augustus') is paired with conquest over nature.

natura melior potentiorque.

hic siflammigeros teneret axes,

$30 \quad$ See R. Nisbet, 'Virgil's fourth Eclogue: easterners and westerners', Bulletin of the Institute of Classical Studies 25 (1978), 59-78, esp. 62 on the nascitur/nascenti echo.

31 This literalization may even constitute an intertextual correction of Vergil's notorious mixing of linear and cyclical conceptions of history in the Fourth Eclogue. See Nisbet 1978, op. cit. (n. 30). 
largis, India nubibus maderes, undaret Libye, teperet Haemus.

Stat. silv. $4 \cdot 3 \cdot 135^{-13} 8$

Better and mightier than Nature, if he had the flaming sky in his keeping, India would be damp with generous clouds, Libya watered, Haemus warm. (translation modified)

Here Statius baldly asserts Domitian's control over nature through a series of adynata (droughts overtaken with rain, deserts flooded, cold climates made warm). These adynata obviously echo, at least in a general way, those of the Golden Age in Eclogue 4 (very little need for agricultural labor, no snakes, pre-dyed wool, etc.). In addition, however, the toponyms in Statius' list of adynata point forward to the 'map' of imperial conquest, based on Vergil's, which appears later in the Sibyl's speech (lines 153-157, quoted above). Both lists refer to the extremes north, south, and east of the empire. In this way, military victory becomes a figure for control over nature, ${ }^{32}$ which itself is merely a hyperbolic statement of what Domitian has literally accomplished in the road building project. In the Statian Sibyl's speech, then, both the pastoral Golden Age of the Fourth Eclogue and the imperial Golden Age of the Aeneid are literalized in the construction of the road and its concomitant transformation of the landscape. In simple political terms, Domitian's infrastructure policies have brought into existence the content of Augustan-era propaganda by physically improving the agricultural prospects of coastal Campania.

\section{The Ode to Septimius Severus}

Silvae 4.5 is the only example of Alcaics in the collection. ${ }^{33}$ The poem is addressed to a certain Septimius Severus, possibly an ancestor of the $3^{\text {rd cen- }}$ tury emperor. ${ }^{34}$ Severus hails from Lepcis Magna in North Africa and has become integrated into Roman society as an equestrian. The poem's primary

\footnotetext{
32 Cf. Kleiner 1991, op. cit. (n. 11).

33 On this poem see D. Vessey, 'Non solitis fidibus: some aspects of Statius Silvae IV, 5, AC 39 (1970), 507-518; K. Coleman, 'An African at Rome: Statius, Silvae 4.5', Proceedings of the African Classical Association 17 (1983), 85-99, esp. 85-89; D. Spencer, 'Singing in the garden: Statius's plein air lyric (after Horace)', in J. Blevin (ed.), Dialogism and Lyric Self-fashioning: Bakhtin and the Voices of a Genre (Selinsgrove 2008), 66-83; Nagel 2009, op. cit. (n. 6).

34 See Coleman 1983, op. cit. (n. 33); R. Nauta, Poetry for Patrons (Leiden 2002), 218-220.
} 
conceit is the view that Severus does not seem at all like a foreigner but acts like a Roman through and through (see esp. lines 29-47). The poem closely parallels Horace's Grosphus Ode (2.16) and its celebration of the simple life. ${ }^{35}$ Statius' narrator begins by proclaiming, in Horatian terms, his happiness with the simple life of the countryside (parvi beatus ruris honoribus, Silv. 4.5.1). ${ }^{36}$ This assertion echoes the Horatian narrator's satisfaction with a small farm (mihi parva rura / ... / Parca non mendax dedit, Carm. 2.16.37-39) and simple living (vivitur parvo bene, Carm. 2.16.13). Statius then contrasts his own position as a rural smallholder to those with vast estates and enormous flocks of animals (i.e., people like the Horatian Grosphus): ${ }^{37}$

non mille balant lanigerigreges,

nec vacca dulci mugit adultero

Stat. silv. 4.5.17-18

[To me] no bleat of a thousand woolly flocks, no lowing of cow for her sweet paramour ...

te greges centum Siculaeque circum

mugiunt vaccae, tibi tollit hinnitum

apta quadrigis equa ...

Hor. carm. 2.16.33-36

All around you a hundred herds of Sicilian cattle low; you have a whinnying mare just right for the four-horse chariot ...

In Horace' list te refers to Grosphus, who stands in contrast to the Horatian narrator and his contentedness with his small fields (Carm. 2.16.37, quoted above). Statius has appropriated this contrast and placed himself in the position of the Horatian narrator. ${ }^{38}$ This is further emphasized by the fact that Statius also likens his dwelling to that of Horace in the famous Soracte Ode:

nos parce tellus pervigil et focus

culmenque multo lumine sordidum

35 Hardie 1983, op. cit. (n. 6), 144 (who sees other sources as well).

$36 \quad$ K.S. Myers 'Miranda fides: poet and patrons in paradoxographical landscapes in Statius' Silvae', MD 44 (2000), 103-138, esp. 131. Cf. Spencer 2008, op. cit. (n. 33), 68.

37 S. Newmyer, The Silvae of Statius. Structure and Theme (Leiden 1979), 43.

38 Spencer 2008, op. cit. (n. 33), 68. 
solantur exemptusque testa

qua modo fer $<b>$ uerat Lyaeus.

Stat. silv. 4.5.13-17

To me a patch of land, an unsleeping hearth, and a roof darkened by abundant light bring comfort, along with Lyaeus taken from the jar in which lately he had fermented.

dissolve frigus ligna super foco large reponens atque benignius deprome quadrimum Sabina, o Thaliarche, merum diota ...

Hor. carm. 1.9.7-8

Thaw the cold by piling logs generously on the hearth, Thaliarchus, and serve the four-year-old wine more lavishly than usual from its Sabine jar ...

Here, the intertext compares Statius' estate and style of living to those of Horace. The straightforward interpretation of the entire Horatian intertext is that Statius is establishing his poetical credentials by comparing himself to Horace, and by embedding himself in a Horatian (figurative) landscape.

The middle section of the poem (21-28) describes the personal relationship between Statius and Severus. Severus is then introduced $(29-40)$ and given the role of Grosphus: he owns three separate estates in the Italian countryside and is involved in politics (41-56; cf. Carm. 2.16.9-10 for Grosphus' political interests). Of course, Statius does not criticize Severus as Horace does Grosphus, but instead asserts that, in spite of their economic and political differences, both he and Severus share the same poetical interests $(57-60){ }^{39}$

Statius' praise of Severus also contains many Horatian inflections. This is particularly evident in Statius' contrast of Severus' public and private personae:

est et frementi vox hilaris foro;

venale sed non eloquium tibi,

ensisque vagina requiescit,

stringere ni iubeant amici.

sed rura cordi saepius et quies ...

Stat. silv. 4.5.49-53

39 Nagel 2009, op. cit. (n. 6), 149-15o. 
Cheerful your voice ever when the Forum roars, but your eloquence is not for sale; your sword sleeps in its scabbard unless your friends tell you to draw it. But more often rest and the countryside is to your mind ...

Statius assertion that Severus' oratorical talents cannot be purchased echoes Horace's sentiment that otium cannot be purchased even with Grosphus' great wealth: neque purpura ve/nale nec auro (Carm. 2.16.7-8). Severus' talents remain at rest (requiescit, 50) like a sword in its sheath, only brought out (presumably for free) to benefit his friends. Thus, when Statius asserts that Severus prefers the peace (quies, 53) of the countryside, this too has a Horatian inflection. For Statius as for Severus, then, the rural landscape is a Horatian space. This equivalency seems guaranteed both by the common poetical interests of the two men and by the fact that Severus' very identity as a Roman is implicated in a further Horatian intertext:

\author{
non sermo Poenus non habitus tibi, \\ externa non mens: Italus, Italus. \\ sunt Vrbe Romanisque turmis \\ qui Libyam deceant alumni \\ Stat. silv. $4 \cdot 5 \cdot 45^{-48}$
}

Your speech was not Punic, nor foreign your dress or your mind: Italian, Italian! In the City and Rome's squadrons there are some worthy to be fosterlings of Libya.

Scholars have pointed out that the exclamation Italus, Italus echoes Horace's Juno in the third Roman Ode when she refers to the destruction of Troy: Ilion, Ilion (Carm. 3.3.18, in the same sedes). ${ }^{40}$ The context of this passage is Horace's version of Juno's 'surrender' speech in which she agrees to stop persecuting the Trojans if they abandon their old identity and become Romans (cf. Aen. 12.807-828). Evidently Severus is Roman 'from the beginning' (i.e., since the Trojan conversion). Statius has thus characterized Severus' lifestyle as properly Horatian in spite of his surface similarities to the (anti-Horatian) Grosphus: Severus has achieved Horace's epicurean otium even though he possesses Grosphus-sized estates.

Is it possible to see Statius reversing these metaliterary figures? In what follows I illustrate how Statius appropriates an intertext already present in Horace 
to emphasize the physical landscape of his and Severus' estates. Horace, in the Grosphus Ode, echoes Lucretius' criticism of luxury as superfluous to the epicurean good life:

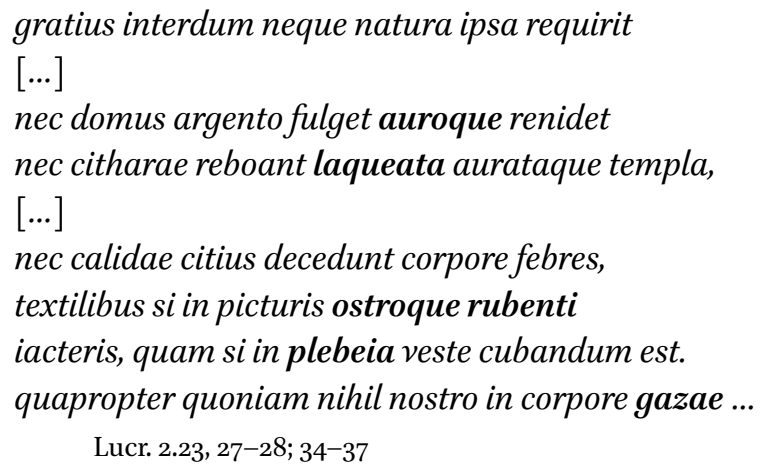

... nor does nature herself ever crave anything more pleasurable $[\ldots]$ if the hall does not shine with silver and glitter with gold, if no crossbeams paneled and gilded echo the lyre [...] And no quicker do hot fevers fly away from your body, if you have pictured tapestry and blushing purple to toss upon, than if you must lie sick under the poor man's blanket. Therefore, since treasures [profit] nothing for our body ...

otium bello furiosa Thrace,

otium Medi pharetra decori,

Grosphe, non gemmis neque purpura ve-

nale neque auro.

non enim gazae neque consularis

summovet lictor miseros tumultus

mentis et curas laqueata circum

tecta volantis.

Hor. carm. 2.16.6-12

A quiet life is the prayer of Thrace when madness leads to war. A quiet life is the prayer of the Medes when fighting with painted quivers: a commodity, Grosphus, that cannot be bought by jewels or purple or gold. For no riches, no consul's lictor, can move on the disorders of an unhappy mind and the anxieties that flutter around coffered ceilings.

Both poets criticize coffered ceilings, crimson garments, and Persian-style treasure. This of course constitutes an appeal to authority on Horace's part 
for his own moralizing against luxury. ${ }^{41}$ Statius, for his part, acknowledges the Lucretian background of his Horatian model through his own combinatory allusion to Lucretius. In the description of the coming of Spring at the beginning of his poem, Statius says that "the sea and earth smile" (iam pontus ac tellus renident, Silv. 4.5.7). This phrase combines two references to Lucr. The first is to Lucretius' famous proem: tibi suavis daedala tellus / summittit flores, tibi rident aequora ponti / placitumque nitet diffuso lumine caelum (Lucr. 1.7-9, "for you the wonder-working earth puts forth sweet flowers, for you the wide stretches of ocean laugh, and heaven grown peaceful glows with outpoured light"). ${ }^{42}$ The second reference is to the description of luxury in Lucr. 2, itself alluded to by Horace: nec domus argento fulget auroque renidet (Lucr. 2.27, "if the hall does not shine with silver and glitter with gold"). By juxtaposing the good life of Lucr. 2 and the natural world of Lucr. 1, Statius reminds his readers that epicurean ethics have their basis in epicurean physics. Statius has thus 'corrected' Horace's moralizing (for which the landscape is a figure) and thereby 'naturalized' the Horatian landscape. In Horace, the Sabine Farm is symbolic of epicurean simplicity. In Statius, both his Alban estate and the various estates of Severus exist within physical world: they are all 'real' (i.e., material) possessions that have been acquired through real-life means. For Severus, his own wealth has enabled him to purchase, and to rest peacefully in, his many estates. This is quite unlike the Horatian Grosphus, who can evidently find no peace despite all his real estate. For Statius himself, imperial patronage is the source of his livelihood and hence his enjoyment of rural simplicity (see Silv. 4.5.23-24). ${ }^{43}$ Statius reveals Horace's own privileged position vis-à-vis the imperial regime and connects this to the physical possession of the famous Sabine farm. Statius has, in any case, employed the Horace-Lucretius intertext as a figure for the economics of quies, including the possession of pleasant country estates. Severus, like Horace, is a good Roman because he can afford to be. This revelation of the commercial aspects of country living may still mystify the underlying politics of exploitation inherent in the imperial economy taken as a whole,${ }^{44}$ but it is a long way from the nearly pure aestheticization of the landscape in Horace.

\footnotetext{
41 Note also that the intertextuality of Horace's moralizing also problematizes it!

42 Coleman 1988, op. cit. (n. 6), 162 points out that renidere can be a synonym for ridere.

43 Cf. Nagel 2009, op. cit. (n. 6), 15o. Cf. Nauta 2002, op. cit. (n. 34), 335-336, on Domitian's patronage of Statius generally.

44 Cf. Leigh 2016, op. cit. (n. 1), on economic mystification in Vergil's Eclogues.
} 


\section{$5 \quad$ Conclusion}

We have seen how it is possible to catch a glimpse of the impact of imperial politics on the landscape in Statius' Silvae. We have examined instances in which Statius has appropriated figured landscapes from his literary predecessors. These landscapes include the pastoral Golden Age, prehistoric Italy in the Aeneid, and Horace's rural retreats. In each instance, Statius may be understood as importing the politics that the intertextual landscape represents and reversing the trope so that these politics inform his own representation of the landscape. In Vulturnus' speech the Vergilian Golden Age is an agricultural metaphor that praises the improvements resulting from the channelization of river. ${ }^{45}$ The Sibyl's speech appropriates the imperial history and military conquest of the Aeneid as a kind of aesthetic by which we view the (newly accessible) Campanian coast. This time, the figure also appropriates cosmic imagery to explain Domitian's overall control over the landscape. The Severus Ode reveals the economic underpinnings of Horace's rural moralizing by returning the Horatian landscape to the physical world. Obviously, the impact of empire on the Italian landscape is a much more complicated phenomenon than I have outlined here. But I think the principles I have put forth can usefully be employed in making inroads into a better understanding of the phenomenon.

45 This in many ways parallels Statius' praise of Domitian's "Vine Edict" earlier in the poem (Silv. 4.3.11-12). 